\section{Worse than picking up pins? The search for dressmakers in nineteenth-century New Zealand}

\section{JANE MALTHUS}

One of the first jobs a dressmaking apprentice in the DIC workroom in Dunedin in the 1890 s learned to do was to pick up the pins. For some young girls this was all they did for the first few weeks of their employment. For me, the task of rediscovering the work of dressmakers in nineteenth century New Zealand has been similar, in that there are always (it seems) more pins to pick up, more sources to locate. It has been worse too, because unlike the pins the sources are often not obvious, and certainly not all in the one room or institution. However, I have found the task infinitely more enjoyable and satisfying than my experiences of picking up pins.

The discussion which follows focusses on the variety, and scarcity, of sources I have used in investigating how dressmakers worked last century, a study still in progress. It is part of a larger investigation into aspects of European women's dress in colonial New Zealand, in which I am seeking to ascertain whether women settlers really did adapt their clothing to the frontier-like conditions they found themselves in, as some writers have claimed, or if they continued to follow the lead of Britain and Europe and change the style of their clothes as fashion dictated. Evidence of dressmaking expanding as an occupation as the colony developed would imply that some interest in keeping up with changing fashions was present, otherwise purely functional garments could continue to be made within the family economy.

From the available sources it is difficult to obtain clear evidence of the number of women working as dressmakers in nineteenth century New Zealand. The number fluctuated as women moved in and out of the trade according to their circumstances. Young single women might train and start their own businesses but cease work on marriage or childbirth.

For women forced to take up employment through widowhood or unexpected poverty, dressmaking or another of the related sewing trades was an obvious choice, but if their financial security improved it was just as easily given up. Newspaper advertisements, such as one appearing in the Otago Witness, 12 October 1860 , which indicated that Miss J. Stewart had commenced as a dressmaker, and orders for her could be left with Mr.Hood, Merchant Tailor and General Draper, provide some evidence of movement into and out of the dressmaking business.

These advertisements are useful illustrations of the variety of ways dressmakers worked, but do not allow even for estimates to be made of the numbers working in a community at any particular time, since many women relied on word of mouth alone to obtain clientele, or worked as in - or out - workers for established dressmakers. Newspapers do provide evidence of businesses continuing and expanding. For instance, a Mrs. Campbell, who had been in business for at least three years according to a succession of advertisements in the Otago Witness, wanted to employ a number of dressmakers early in $1861 .{ }^{2}$

Almanacks and street directories are also an unreliable quantitative source, even though they usually included the occupation 'dressmaker' in the street directory, and often featured dressmaker's advertisements in the trade section.

88 ADPEETIEEMEKTE.

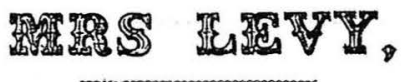

\section{BABY LINEN WAREHOUSE}

$$
\begin{aligned}
& \text { LAMBTON QUAY, } \\
& \text { OPPOBATE TME OD@ FEBLLOWS' MALL, } \\
& \text { MILLINERY OF ALL DESCRIPTIONS. }
\end{aligned}
$$

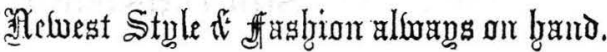

JW

\section{MILLINER AND STRAW HAT}

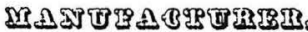

CUBA STREET, WELLINGTON, NEW ZEALAND.

Ostrich Feathers, Hats and Bonnets, Cleaned and Dyed.

\section{Hat MILLINER AND DRESSMAKER, \\ ILAMTON QUAT,}

WELLINGTON, N EW ZE\&LA ND.

Wellington Almanac, 1873.

Beaglehole Room, V.U.W. Library 
It is difficult for us to know how accurate, comprehensive and up-to-date the information was, . or how the term 'dressmaker' was applied.

Comparing the 1890 Wellington Almanack · with the data on dressmakers included in the report of the 1890 Sweating Commission there is some agreement on the names and numbers of dressmakers operating in Wellington in 1890 but the lists are not identical.

Almanack listings are useful as indications of trends and changes as settlements developed and enlarged. In Wellington, for example, in the early 1860 s the majority of milliners and dressmakers worked from addresses on Lambton Quay, but by 1890 land values and rebuilding along the Quay had forced these smaller businesses to the outskirts of the commercial area: Upper Willis Street, Cuba Street and Courtenay Play. It is also evident from Wellington almanack listings that many dressmakers throughout the period ran their businesses from their own homes - in Thorndon or along
Taranaki Street for example.

Some information about the numbers of dressmakers working in late nineteenth century New Zealand is available from the censuses taken from 1867 onwards. The first two censuses are of no assistance though, since the occupational classes listed are broad categories only with no further breakdown offered. Dressmakers may have been categorised in 'Trade, Commerce and Manufactures', or in 'Mechanics, Artificers, and Skilled Workers', or both, depending on whether they were employer or employee, or put in the miscellaneous column; in any case they are inseparable and invisible.

By 1874 , however, the information on occupations is much more specific, and illustrates the fragmentation within the clothing industry. In the sub-order 'Dress' there are fourteen separate categories, including 'Milliner, Dressmaker', 'Shirtmaker, Seamstress', 'Tailor, Tailoress', and 'Hat, Cap Maker, Straw Hat, Bonnet Maker.' These separate and even hierarchical categories

TABLE 1: NUMBER OF PERSONS OCCUPIED AS MILLINER, DRESSMAKER

$\begin{array}{lrrlll}\text { Year } & \begin{array}{r}\text { Total } \\ \end{array} & \text { Male } & \begin{array}{l}\text { Female } \\ \text { Workforce }\end{array} & \begin{array}{l}\text { Female } \\ \text { Workforce* }\end{array} & \begin{array}{l}\text { \% of female as } \\ \text { Milliner Dressmaker }\end{array} \\ 1874 & 2039 & & 2039 & 14483 & 14.1 \\ 1878 & 2858 & & 2858 & 21356 & 13.4 \\ 1881 & 3658 & & 3658 & 24826 & 14.7 \\ 1886 & 5472 & & 5472 & 32580 & 16.8 \\ 1891 & 6613 & 11 & 6602 & 42992 & 15.4 \\ 1896 & 7441 & 8 & 7433 & 51589 & 14.4\end{array}$

*Female Workforce totals taken from Keith Rankin, New Zealand's Labour Supply in a Long Term Perspective, Papers for the New Zealand Association of Economists Sesquicentennial Conference, 1990.

Source: New Zealand Censuses 1874 - 1896.

TABLE 2 : NUMBER OF PERSONS OCCUPIED AS TAILOR, TAILORESS

\begin{tabular}{lcrrrc}
$\begin{array}{l}\text { Year } \\
\text { Workforce }\end{array}$ & Total & Male & Female & Female & $\%$ Female \\
& & & \multicolumn{2}{c}{$\begin{array}{c}\text { Workforce } \\
\text { as Tailoresses }\end{array}$} \\
1874 & 809 & 666 & 143 & 14.483 & 1.0 \\
1878 & 1207 & 915 & 292 & 21356 & 1.4 \\
1881 & 1457 & 1041 & 416 & 24826 & 1.7 \\
1886 & 2358 & 1289 & 1069 & 32580 & 3.3 \\
1891 & $4254^{*}$ & 1704 & 2550 & 42992 & 5.9 \\
1896 & $4561^{*}$ & 2108 & 2453 & 51589 & 4.8
\end{tabular}

* In 1891 the category changes to Clothing Manufacturer, Tailor, Cutter, Fitter, Sewing Machinist.

Source: New Zealand Censuses 1874 - 1896. 
were maintained and fostered by their participants. While the term needle-women applied to all females who earned a living by sewing, there were several distinct trades. Dressmakers specialised in the creation of fitted dresses for women, and made mantles, robes, cloaks and sometimes also underclothing. They were regarded as being at the top of the hierarchy because of the intricacy and skill in their work. Seamstresses were employed by dressmakers, draper's stores, or contractors in-house or as out-workers to stitch and finish garments for males or females, and sewed by hand or machine. Milliners had traditionally furnished entire costumes for their clients, but during the nineteenth century increasingly specialised in headwear production.

In New Zealand up until the 1890s, it was usual for women to offer both millinery and dressmaking services to their clientele, except straw hat or bonnet making which seems to have separated early. Mrs. R. Wakelin of Willis Street, advertised in the 1852 Wellington Almanack informing 'the ladies of Wellington, that she is prepared to make up Caps, Bonnets, Polka Coats, Dresses, Frocks etc. in the best Style, and at the Lowest Price'.

Tailors, almost exclusively males, hired women to carry out routine sewing hence the name tailoresses, which later described all women employed on the production of men's garments including shirts, vests, trousers and hosiery.

From the 1874 census until that of 1896 the categories used remain more or less constant so the number of persons classified as milliners and dressmakers can be identffied (see Table 1). For comparison Table 2 shows the numbers occupied as tailors and tailoresses over the same period, and highlights the feminisation of the men's clothing trade as industrial machinery and mass production replaced hand tailoring.

At the 1901 census, the occupational categories for the clothing industry change so drastically that further tabulation is meaningless. The changes no doubt reflect those occurring within the industry because of mechanisation, industrialisation and specialisation. Instead of 'Milliner, Dressmaker' as a category 'Clothing Manufacturer, Tallor, Dressmaker' appears, perhaps indicating that these people are now more likely to be employers of others rather than individuals working at their own trade. The occupation 'milliner' is grouped with 'staymaker' and 'glovemaker' as a specialist clothing article producer.*

Although only rough estimates, therefore can be made of the numbers of women (and men) working as dressmakers, and then only for part of the period, some aspects of their work are documented. Advertisements in newspapers

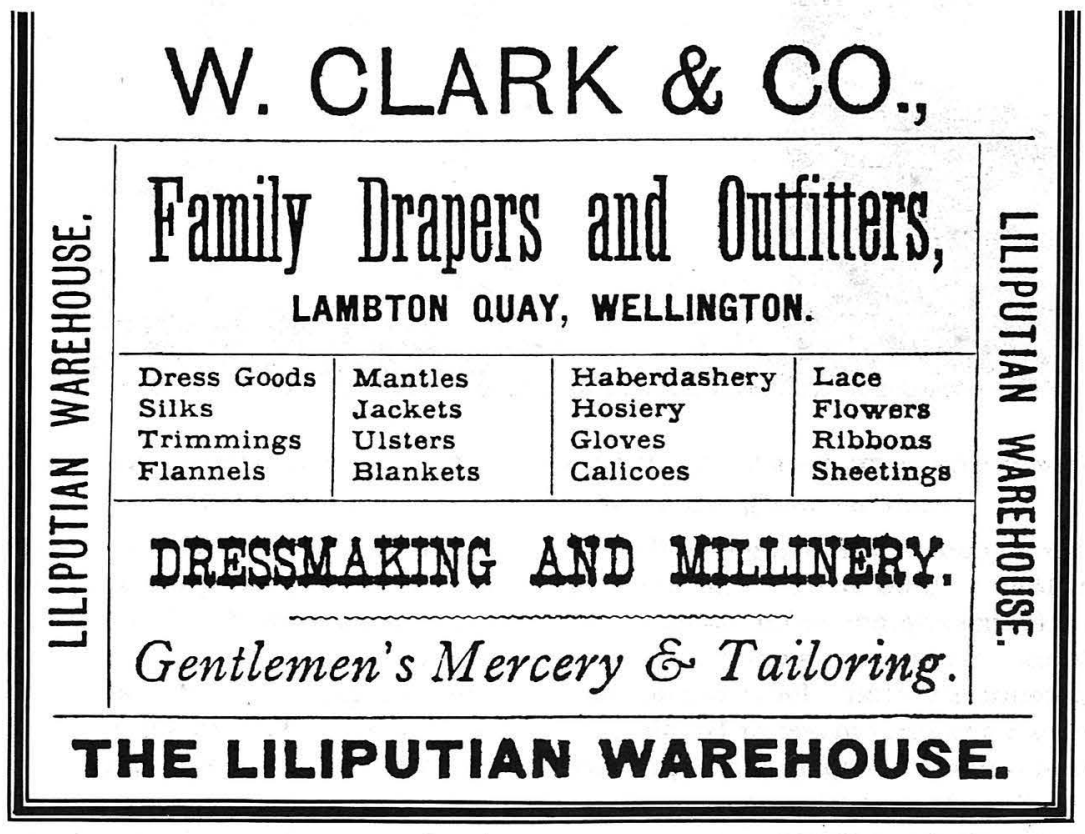

Wellington Almanack, 1888. Beaglehole Room, V.U.W. Library 


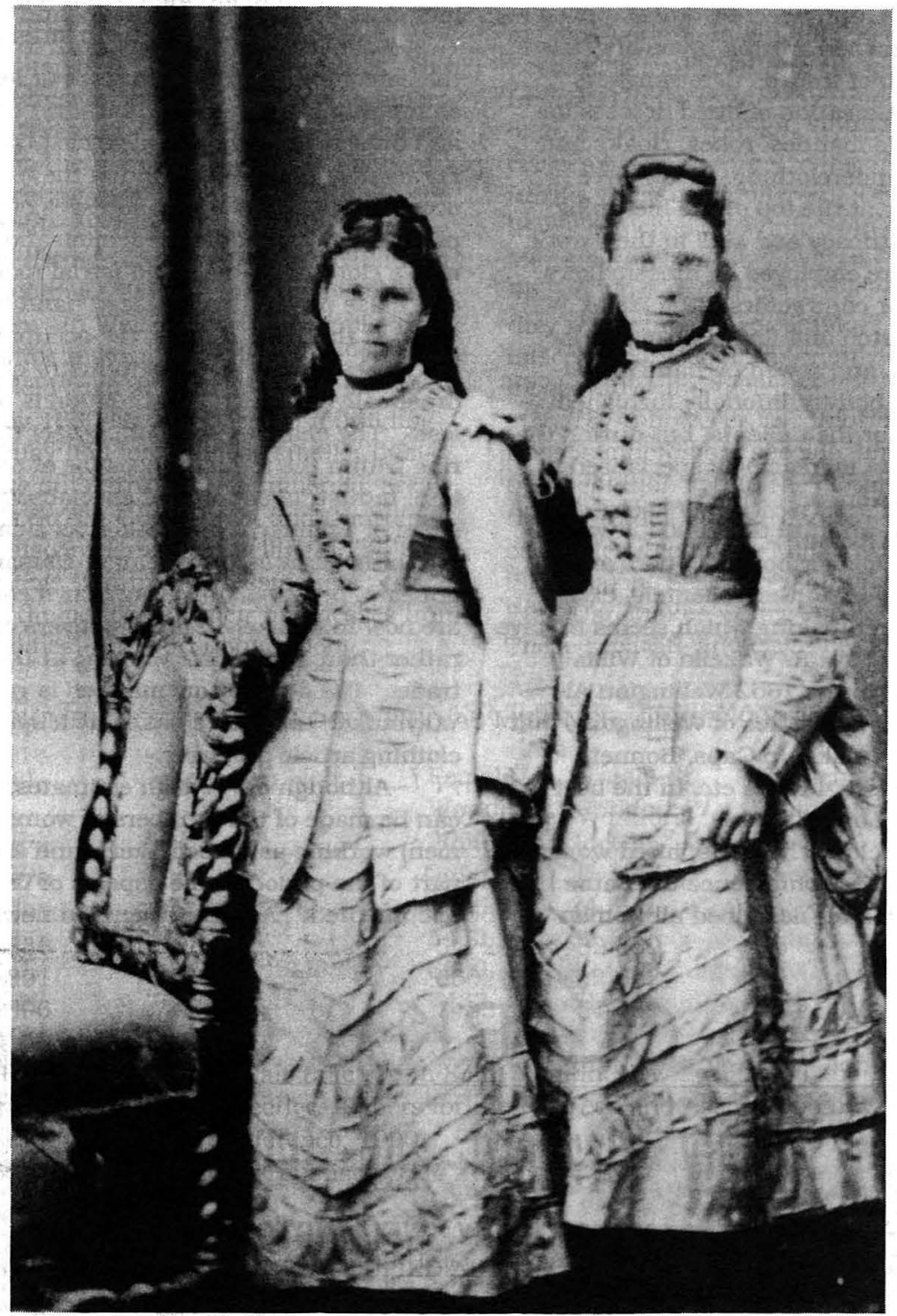

Whether these dresses were made by the wearers, a dressmaker, or in a drapery workroom, is unknown Gardiner family album, Port Chalmers. Photographer unknown.

published throughout New Zealand over the period from 1840 to 1900 indicate that there was at least an informal apprenticeship system operating in the colony. Dressmakers advertised for apprentices to train: for example, Mrs. Coles, a milliner and dressmaker of Trafalgar Street, Nelson wanted to employ four apprentices in March, 1943." Drapers wishing to set up dressmaking departments attached to their stores would call for 'first-class' milliners and dressmakers.- a term used to describe those who had been through a system of apprentice, journeywoman, third and second classes, and were now at the top of the trade. Others would stress the quality of their staff by indicating that they had worked in first class establishments elsewhere before emigrating to New Zealand. : Because the system of training was informal with no established guild or trade organisation to oversee conditions of work, it was easily 
abused, as Jeanine Graham has discovered in her work on the employment of children. Girls, often less than fourteen years of age, were taken on for up to one year without pay to learn the sewing trade, but were discharged as soon as they became entitled to wages. A fresh group of girls was then taken on....

Further illustration of the operation of an apprenticeship system is found in the report of the 1890 Sweating Commission, 'appointed to inquire into certain relations between the employers of certain kinds of labour and the persons employed therein.' One of the 'certain kinds of labour' was needle-work. The testimonies of many women who appeared before the Commission showed that while the system of training had become more organised by 1890 , wages and conditions were variable and there was no standard practice of teaching apprentices so that they would experience the range of activities involved in garment production. One young woman stated that she was a dressmaker but 'not yet a competent hand' so her brother was 'going to pay a premium for me to learn the trade'...

Newspaper and trade directory advertisements indicate that many dressmakers ran their own businesses from either their homes or premises in or near the commercial areas of settlements. Some dressmakers operated in conjunction with drapers, sharing business accommodation and presumably customers, or were hired by the draper to provide his clientele an added service."

These sources though, are silent on those dressmakers who were out-workers, or those who worked for families in their homes, travelling from one to another and staying as long as needed to replenish wardrobes with new clothing and household cupboards with new or refurbished sheets, pillowcases and other items. Word of mouth advertising was usually all these seamstresses needed to keep up the supply of work, and so they are difficult to trace.

A few manuscript sources illuminate aspects of this work. A Mrs.Nilsson, who came to New Zealand from Sweden in 1873, went to a Mrs. Williams in Wellington during the day to assist her with sewing in return for English lessons." Catherine Hester Ralfe obtained out-work making mantles for 'a kind of drapers shop' run by Mrs. Black in Colombo Street, Christchurch, in the mid 1860s. She was lucky enough to possess her own sewing machine, a farewell gift from her uncle in England, which enabled her 'to take this kind of work'. "

While finding such references is a highlight within the research process, they do raise a number of questions. How representative were these experiences of other women who worked as dressmakers? How many other seamstresses or dressmakers owned their own sewing machine? Did those who travelled from house to house have access to a sewing machine there, or were they expected to bring one with them? The

\section{MRS. QUAINTANCE,

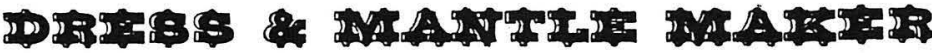 \\ ingestre street, Nrar Panama Hotel.}

Robes and Costumes made in the newest style. Ladies' Patterns and fitted, and their own materials made up. Orders promptly attended to.

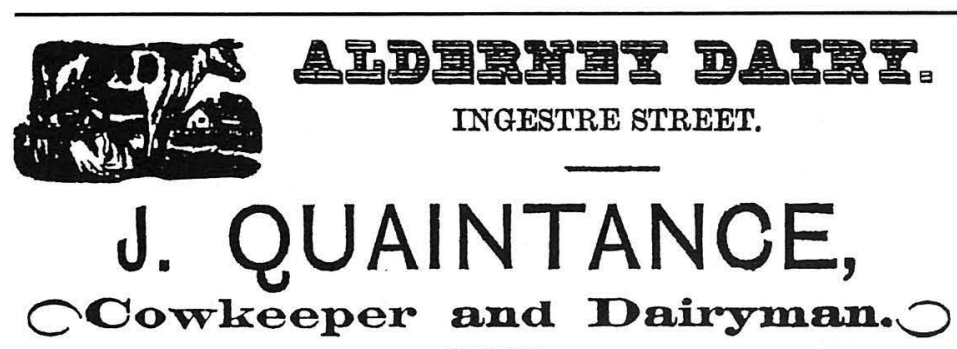

Families supplied with New Milk and Oream at ang hour of the day. 
sources are not clear. Most of the women who worked in this way have not left the kinds of records which appear in the public or research libraries, at least not yet. There are no work records, very few diaries and only a few dressmaker labelled garments in the public collections, although there are examples in some museums of dresses with labels to indicate that they were made in draper store workrooms. These and other questions about the work of dressmakers, and other needlewomen, in nineteenth century New Zealand I have yet to answer fully. It would be interesting to know more about the availability of paper patterns, for instance, which were circulating in some countries in the 1860 s to trade customers, and were more generally available in the 1870 s. When did dressmakers in New Zealand gain access to such aids? Was information about the latest fashions overseas shared with colleagues, or were dressmakers then, as they tend to be now, working in virtual isolation from one another, perhaps competing for business and therefore keeping their sources of fashion information and patterns to themselves? There are many more pins to be found, let alone picked up.

\section{Footnotes}

1. e.g., Jeanine Graham, 'Settler Society', in W.H. Oliver with B.R. Williams (eds), The Oxford History of New Zealand, Oxford.

2. Otago Witness (OW), 21/1/1861.

3. A. Penney discusses the accuracy of information in almanacks in 'Almanacs and Directories', The New Zealand Genealogist 14, 134, May 1983, pp.310-5

4. Wellington Almanack, Directory, Calendar, Diary and Nautical Almanack for the Year 1890. Wellington, J. Chantrey Harris.

5. Report of the Royal Commission Appointed to Inquire into Certain Relations Between the Employers of Certain Kinds of Labour and the Persons Employed Therein (The Sweating Commission), Appendices to the Journals of the House of Representatives (AJHR), 1890, H-5, Report of D. O'Rourke, Inspector of Factories, Wellington, p.97.

6. Statistics of New Zealand for 1867 including the Results of a Census of the Colony taken in December of that ear. Wellington: 1869. Table 13. New Zealand Census, $1871 \mathrm{~m}$ Table 13.

7. New Zealand Census, 1874, Part VI. Occupations of the People, Table LX, p. 159.

8. e.g., OW 16/1/1858, Mrs. Campbell hands over the straw bonnet business to Miss Jessie Campbell. Hawkes Bay Herald (HBH) 3/9/1852, Mrs. Shep herd advertises as a straw hat and bonnet maker. InThe Penny Journal , 14/7/1866, Jenkins and Company, Auckland, state that they employed a first class straw worker from Luckman and Co., Straw Hat Manufacturers, Luton and London.

9. The Wellington Almanack for 1952, Wellington: Wellington Independent, p.xxx.

10. New Zealand Census, 1901, Occupations of the People, Table IX, p.335.

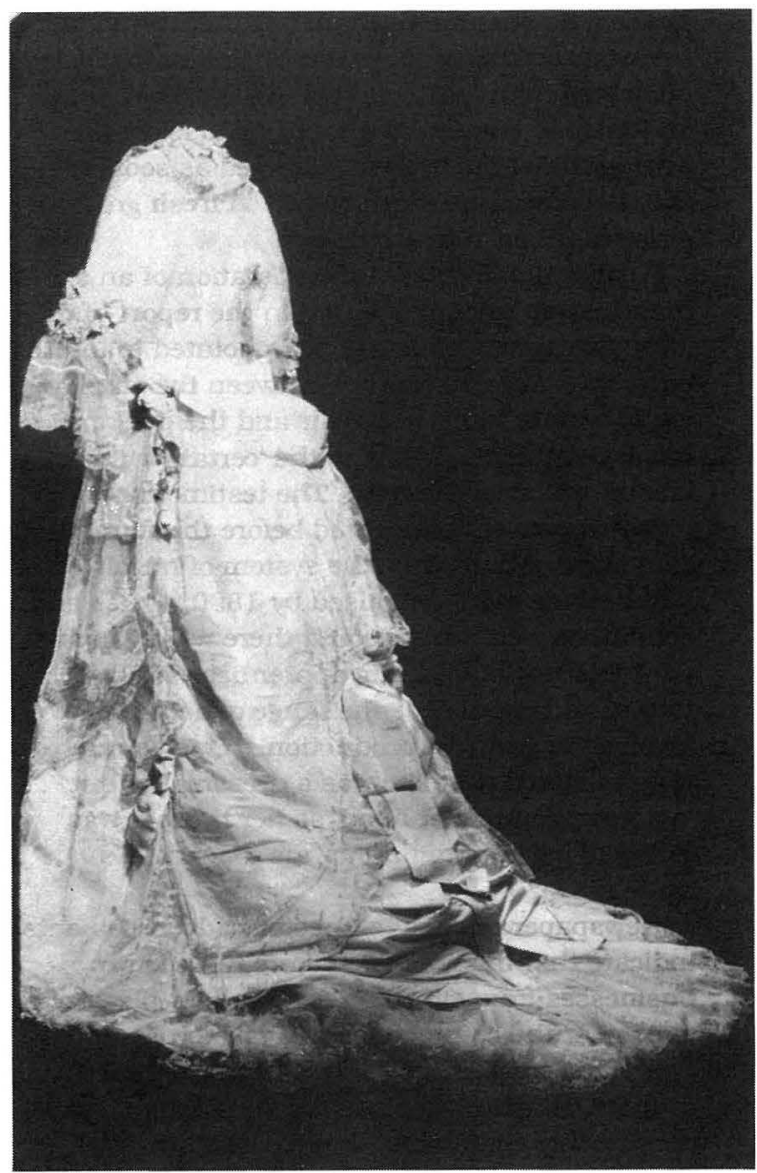

Silk taffeta and net lace dress worn by Anne Holmes at her marriage to John White in the 1870 s. Inside label indicates that it was made in Brown Ewing's dressmaking workroom. Otago Early Settlers Museum, Dunedin Photo: Jane Malthus

11. Nelson Examiner (NE) $25 / 3 / 1843$, p.217,

12. e.g., OW 5/1/1861, Mr. C.,T. Ick, a draper, advertised for a first class milliner.

13. e.g., Lake Wakatipu Mail (LWM) 10/2/1864, p.3, Mrs. Burke had managed a first class house in the West End, London, and her employee, Miss Whiting, had worked in Buckley and Nunn's, Melbourne.

14. Jeanine Graham, 'Child Employment in New Zealand', New Zealand Journal of History 21, 2, 1987, p.68.

15. The Sweating Commission, Statement 1860, p.73.

16. e.g., OW $23 / 1 / 1858$, Misses A. and J. Forsyth worked $\mathrm{n}$ conjunction with and upstairs at A .Mollison's drapery in Stafford Street, Dunedin. LWM $1 / 2 / 1865$, p.4, M. and M. McBride offered Millinery and Dressmaking done on the premises by efficient hands from Melbourne and Dunedin:

17. Memoir in private hands.

18. Ralfe, Catherine Hester, Life in New Zealand. 1866 1896, MS Papers 1129, Alexander Turnbull Library. 